\title{
Exploring Agroecological Transition Pathways: The Case of Family Livestock Farmers in Northern Uruguay
}

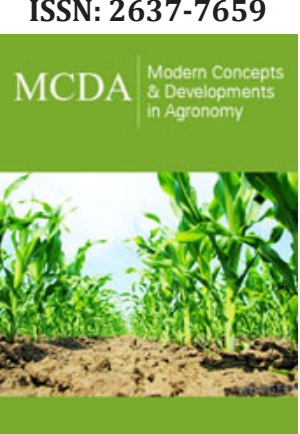

*Corresponding author: Inés Ferreira Rivaben, Experimental Station of the Faculty of Agronomy in Salto, University of the Republic, Uruguay

Submission: 㘹 November 26, 2021

Published: 眥 December 08, 2021

Volume 9 - Issue 5

How to cite this article: Inés Ferreira Rivaben, Mercedes Figari, Virginia Rossi, Mario A Cassinoni, Eduardo Chia. Exploring Agroecological Transition Pathways: The Case of Family Livestock Farmers in Northern Uruguay. Mod Concep Dev Agrono. 9(5). MCDA. 000723. 2021. DOI: 10.31031/MCDA.2021.09.000723

Copyright@ Inés Ferreira Rivaben. This article is distributed under the terms of the Creative Commons Attribution 4.0 International License, which permits unrestricted use and redistribution provided that the original author and source are credited.

\section{Inés Ferreira Rivaben ${ }^{1 *}$, Mercedes Figari $^{2}$, Virginia Rossi ${ }^{3}$, Mario A Cassinoni ${ }^{4}$ and Eduardo Chia $^{5}$}

${ }^{1}$ Experimental Station of the Faculty of Agronomy in Salto, University of the Republic, Uruguay

${ }^{2}$ Institute for Sustainable Development, Innovation and Social Inclusion (IDIIS) Northeastern Regional University Center, University of the Republic, Uruguay

${ }^{3}$ University of the Republic, Uruguay

${ }^{4}$ Experimental Station, Faculty of Agronomy, Universidad de la República Uruguay

${ }^{5}$ INRAE, Montpellier, France

\begin{abstract}
Agroecology represents one of the main alternatives in Uruguay and other countries to production models generated by the green revolution. In Uruguay, agroecology has become more popular but is still marginal, despite the existence of a national plan (Law 19717) that promotes it. The implementation of agroecology needs a knowledge generation system to support it; however, research on agroecological transition processes is still incipient. The objective of this work is to improve the knowledge of the family livestock farmers' decision-making processes through the study of socio-productive practices, and consequently contribute to actions and public policies closer to farmers. The practices highlighted in this work allowed a typology elaboration that represents the possible pathways through which family livestock farmers move towards agroecology. The agroecological transition is conjugated in plural.
\end{abstract}

Keywords: Socio-productive practices and strategies; Agroecological transition; Family livestock farmers

\section{Introduction}

The diverse international experiences in agroecology show that livestock farmers transit towards agroecology through different pathways [1-3]. The way livestock farmers transit towards agroecology is the product of the interrelation of at least three factors: conditions external to the farms at the national level (public policies, research systems, etc.). The way livestock farmer's transit towards agroecology is the product of the interrelation of at least three factors: conditions external to farms at the national level (public policies, research systems, etc.); organizational and local/regional trajectories; and internal farm conditions [4]. These depend on farmers' situations and their projects, which determine the innovation capacities of the livestock farmer families themselves. This model approaches the one proposed by Geels [5] who explains that transitions depend on the interrelation between three dimensions: the socio-technical landscape (public policies, regulations, etc), the socio-technical regime (relations between industry, agriculture, science, market, etc) and innovation niches. In Uruguay, agroecology starts to become important in agricultural production, at the beginning of 2015, when different NGOs propose a Law project that is finally approved on December 11, 2018. This Law $n^{\circ} 19717$ promotes a National Plan for the Promotion of Production with Agroecological Bases and declares of general interest the promotion and development of production systems, distribution and consumption of agroecological products, with the 
objective of fortifying food sovereignty and security, contributing to environmental care, generating benefits that improve inhabitants' life quality (Law ${ }^{\circ} 19717$ ). Regarding livestock, natural pastures occupy more than $70 \%$ of the total exploited area in Uruguay; bovine livestock is the productive specialization of $50 \%$ of the country's agricultural holdings. If we consider ovine livestock, this increases to almost $60 \%$ of farms [6]. Family farming, according to official sources, is a significant social group in Uruguay: 36,965 family farmers in 21,657 holdings are mostly engaged in cattle and sheep production as the main economic activity [7]. Faced with the importance that agroecology is taking particularly in family farms, we wanted to explore how livestock farmers decide whether or not to implement more agroecological production systems, it means exploring innovation niches, according to the proposition of Geels [5]. For this purpose, in the northern region of Uruguay, where livestock activity from natural pastures predominates, we selected a sample of nine livestock farming families where we conducted studies cases (three interviews of more than 2 hours) according to the global farm approach methodology [8], in order to understand the situations, finalities (or objectives), management practices and strategies of the livestock farmers (Figure 1).

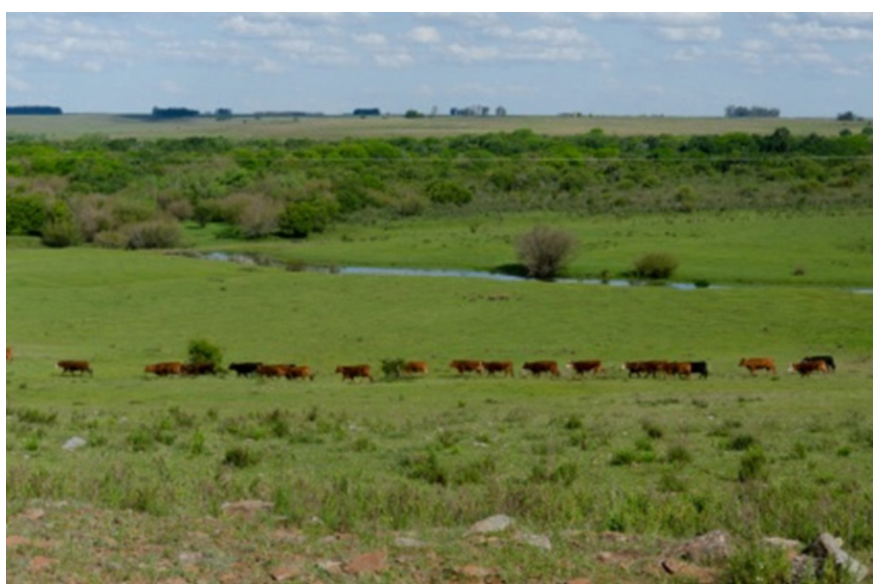

Figure 1: Livestock farming landscape.

\section{Agroecological transition pathways}

The functional analysis of the livestock farmers' practices and strategies allowed us to identify and characterize the farms' trajectories, the decisional rules and the actions of family's livestock farming.

The farmers' objectives act as a framework in which decisions are made. The main finalities found are those related to:
A. The family
i. prioritizing children's education,
ii. maintaining a family lifestyle;
B. The farming system and the livestock farmer's profession:
i. having autonomy as livestock farmers,
ii. being a family farmer,
iii. building a legacy,
iv. developing their own sustainable way of production.

The rules, which make it possible to select the most relevant actions according to finalities, can be classified into three types related to:
A. The family
i. provide children formal education;
ii. ensure the family's welfare;
B. Production
i. diversifying production,
ii. optimizing available resources (Labor, Natural resources, knowledge),
iii. skill training;
C. Economy/organization
i. maintain different income sources,
ii. producing, managing and commercializing collectively.

The strategic common rules associated with socio-productive practices identified in the first analysis were grouped by criteria similarity [9], 3 strategic macro-rules were obtained (i) Social and productive integration; (ii) Focus on productive changes (iii) Improving quality and maintaining a lifestyle.

The actions reflect the way livestock farmers produce, commercialize and operate the system. We can also classify them into three types related to:
A. The family
i. accompanying and stimulating the children's education,
ii. prioritizing family decisions,
iii. self-consumption of the farm's own products;
B. Production
i. use animal health alternatives: homeopathy, biocontrol, biogarrapaticide,

ii. carry out controlled grazing (stocking rate according to grass availability),

iii. rotate pastures to let them rest and seed;

C. Economics/organization

i. sell organic products (meat and wool),

ii. sell secondary products (milk, cheese, vegetables, sweets),

iii. participate in collective projects for family production financed by public policies.

One of our hypotheses regarding the agroecological transition is that there are several pathways and that depends on the 
situation and the project of family's livestock farming. To validate this hypothesis, we constructed a typology based on the models of strategic functioning of the family-farm system obtained from the interviews with the families of the sample of livestock farmers.
The typology makes it possible to group (homogenize) the farms according to function similarity and thus identify the pathways by which it is possible to move towards an agroecological model (Table 1).

Table 1: Agroecological transition paths: typology.

\begin{tabular}{|c|c|c|c|c|}
\hline \multicolumn{5}{|c|}{ Technical-Productive Management Practices } \\
\hline \multirow{2}{*}{$\begin{array}{l}\text { PRODUCTION } \\
\text { OBJECTIVES }\end{array}$} & $\begin{array}{c}\text { Reproduction and animal } \\
\text { health }\end{array}$ & $\begin{array}{l}\text { Concentrated calving and lambing } \\
\text { period. Calves are sold at weaning. } \\
\text { Organic garrapaticide was used. }\end{array}$ & $\begin{array}{l}\text { Concentrated calving and } \\
\text { lambing period, temporary } \\
\text { weaning, fecal worm egg } \\
\text { counting analysis (mostly). } \\
\text { Animal management by category. } \\
\text { Animal selection (fine merino, } \\
\text { texel tattoos). }\end{array}$ & $\begin{array}{l}\text { Long service period, } \\
\text { calving and lambing period } \\
\text { from August. Shearing } \\
\text { in November, sometimes } \\
\text { prepartum shearing. } \\
\text { Calendar health (drenches } \\
\text { every } 2 \text { months). }\end{array}$ \\
\hline & \multirow[t]{3}{*}{$\begin{array}{l}\text { Production and forage } \\
\text { supply utilization }\end{array}$} & $\begin{array}{l}\text { Natural grass quality improvement, } \\
\text { some winter greening and lotus } \\
\text { pasture. High stocking rate, feeding } \\
\text { with pasture rotation by category. } \\
\text { Rearing outside the family farm. }\end{array}$ & $\begin{array}{l}\text { Continuous grazing with } \\
\text { pasture height measurement } \\
\text { (stocking rate relative to the } \\
\text { grass availability). Rational Vosin } \\
\text { grazing (high stocking rate). } \\
\text { Animal category management. }\end{array}$ & $\begin{array}{c}\text { Natural grassland } \\
\text { conservation (few animals } \\
\text { in large areas), some } \\
\text { improvement. Low livestock } \\
\text { density, low stocking density, } \\
\text { low animal rotation. }\end{array}$ \\
\hline & & \multicolumn{3}{|c|}{ Macro-Rules Sheared } \\
\hline & & Social and productive integration & Focus on productive changes & $\begin{array}{l}\text { Improving quality and } \\
\text { maintaining a lifestyle }\end{array}$ \\
\hline \multicolumn{5}{|c|}{ Transition Typology } \\
\hline \multicolumn{2}{|c|}{$\begin{array}{l}\text { Agroecological transition pathways/ } \\
\text { denominations }\end{array}$} & $\begin{array}{c}\text { Exchange and diversification } \\
\text { "Putting your eggs in several } \\
\text { baskets". }\end{array}$ & $\begin{array}{l}\text { Biodiversity management } \\
\text { "Innovating to intensify the } \\
\text { agroecosystem". }\end{array}$ & $\begin{array}{l}\text { Traditional practices } \\
\text { "If it works, don't change" }\end{array}$ \\
\hline
\end{tabular}

The typology allows us to understand the pathway in which livestock farmers move towards agroecology.

\section{The pathway of diversification}

Management practices and strategies are based on natural resources with models (systems, techniques, practices) arising from collective action, as in this case the use of a biogarrapaticide in an associative field. The practices of environmental care have several objectives: to increase the product quality to be commercialized, to take advantage of the potential of the fields without having to invest in external inputs (soil use efficiency), and to start to follow paths (innovations) that make their products better for people's quality of life (use of biological pesticides, stop using glyphosate, carry out rotational grazing with differentiated plots) [10].

\section{The pathway of biodiversity management}

Management practices and strategies are manifested in the complexity of farming systems and propose biodiversity management emphasizing the intensification of agroecosystem technological management with very little use of external inputs. Innovations in production management pursue goals that are related to strong family trajectories, for example: serious health problems in the family that force to change production management for family care. These are changes that follow a defined path, for example, rational Voisin grazing, continuous grazing with stocking rate management according to grass availability, animal category management, incorporation of decision-making tools such as fecal worm egg counting analysis, tattooing of sheep, including the use of biogarrapaticide.

\section{The pathway of traditional practices}

The practices of these livestock farmers are based on the preservation of traditional or peasant practices. They are families deeply attached to their farms for generations, defined by their parents' legacy and by passion for living in farmland. Although the practices are argued by "it has always been done this way" and "do not change what works", they can be modified, which gives these farms a certain resilience or flexibility (Figure 2).

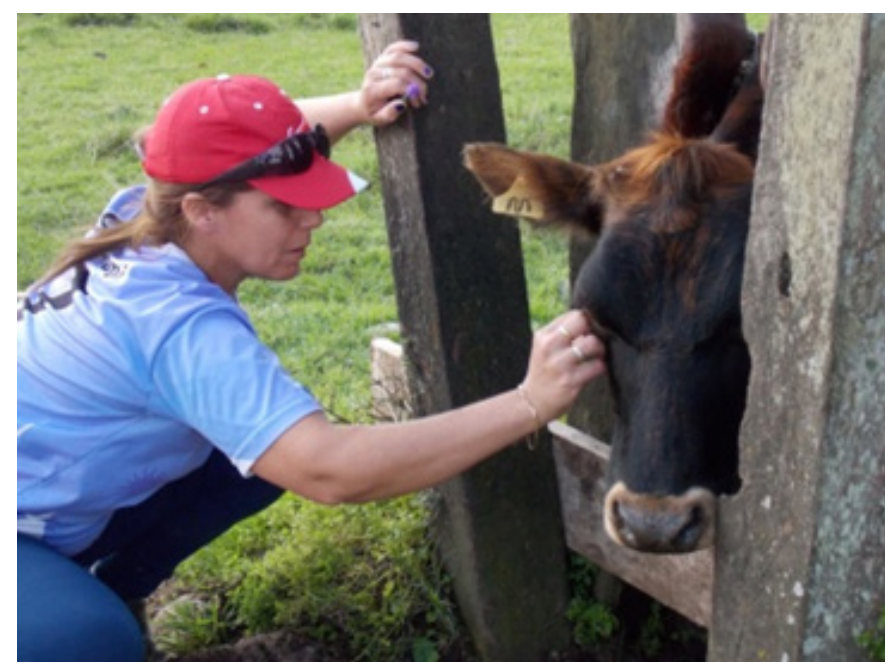




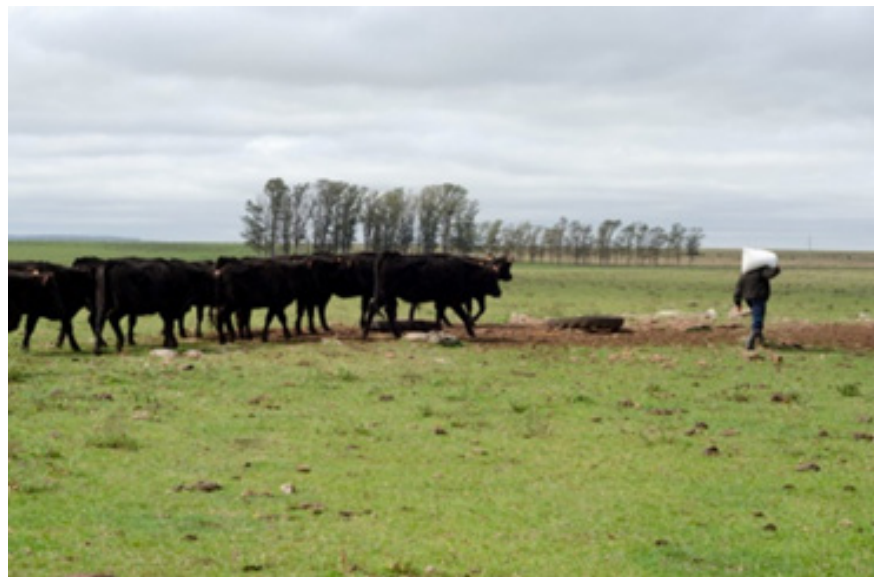

Figure 2: Farmers performing livestock production tasks.9247174128

\section{Conclusion}

The study cases are the first methodological step necessary to understand the livestock farmer families' decisions, the sense of their practices, and why they do what they do. The rules and finalities of each family made it possible to define a "set" of actions practices and strategies that are related to agroecology and that allow us to find different "pathways" of agroecological transition. The typology allows us to visualize: support actions, differentiated and territorialized public policies according to defined transitions types and to incorporate them into the "virtuous circle" of the agroecology. For example, for livestock farmer families that follow the pathway of diversification, we could think of public policies that encourage promotion and commercialization in local markets or local sales of by-products, highlighting their natural characteristics. For those who follow the pathway of biodiversity, in addition to training in biodiversity, public policies could be considered to improve the marketing of organic products (seals, for example) and workshops could be organized to exchange experiences between the territory and farms. And finally, for those families that follow the pathway of traditional practices, it is possible to think about actions to show the sense of being part of the territory, valuing tradition, and based on public policies imagines a proposal for cultural tourism where the territory tradition is highlighted.

\section{References}

1. Altieri M, Nicholls CI (2012) Agroecology: The only hope for food sovereignty and socio-ecological resilience. Agroecología 7 (2): 65-83.

2. Claveirole C (2016) Agroecological transition: challenges and issues. Disponible en línea.

3. Meynard JM (2017) Agroecology, a new relationship to knowledge and innovation. OCL Oilseeds and Fats Crops and Lipids 24(3): 9.

4. Chia E, Petit M, Brossier J (2014) Adaptive behavior theory and family farming. In: L'agriculture en famille: travailler, réinventer, transmettre. INRA-SAD.

5. Geels FW (2011) The multi-level perspective on sustainability transitions: responses to seven criticisms. Environmental Innovation and Societal Transitions 1(1): 24-40.

6. Ministerio de Ganadería, Agricultura y Pesca (MGAP) (2014) Censo General Agropecuario 2011, resultados definitivos. Montevideo: MGAP, Uruguay, p. 142.

7. Ministerio de Ganadería, Agricultura y Pesca (MGAP) (2018) Anuario estadístico agropecuario. Montevideo: MGAP, Uruguay, p. 210

8. Chia E, Téstut M, Figari M, Rossi V (2003) Understand, dialogue, coproduce: reflections on advice in the agricultural sector. Agrociencia 7(1): 77-91.

9. Diéguez F (2014) Study of the operational purposes of a group of extensive family livestock farms. Agrociencia Uruguay18(2): 148-158.

10. Poder Legislativo (2019) Ley $\mathrm{N}^{\circ} 19717$ Declaración de interés general y creación de una comisión honoraria nacional y Plan Nacional para el fomento de la producción con bases agroecológicas, Uruguay. 